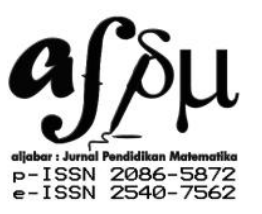

Al-Jabar: Jurnal Pendidikan Matematika

Vol. 7, No. 2, 2016, Hal 267 - 274

\title{
Eksperimentasi Model Pembelajaran Student Facilitator and Explaining (SFE) Terhadap Hasil Belajar Ditinjau Dari Kecerdasan Linguistik
}

\author{
Santi Widyawati \\ IAIM NU Metro Lampung: fredigpsw@gmail.com
}

\begin{abstract}
This study aims to determine: (1) Which gives higher learning outcomes between the Student Facilitator and Explaining (SFE) learning model with the conventional learning model (2) Which gives higher learning outcomes between students with high, medium, or low linguistic intelligence (3) Is there an interaction between the Student Facilitator learning model And Explaining (SFE) and linguistic intelligence on students' mathematics learning outcomes. This research is a comparative causal research with factorial design $3 \times 3$. The conclusion of this research is: (1) There is no difference of learning result of student mathematics between the SFE model with conventional model. (2) There is no difference of learning result of student mathematics observed from linguistic intelligence. (3) There is no interaction between SFE learning model and linguistic intelligence
\end{abstract}

Keywords: Linguistic Intelligence; Mathematics Learning; SFE.

\begin{abstract}
Abstrak
Penelitian ini bertujuan untuk mengetahui: (1) Manakah yang memberikan hasil belajar lebih tinggi antara model pembelajaran Student Facilitator and Explaining (SFE) dengan model pembelajaran konvensional (2) Manakah yang memberikan hasil belajar lebih tinggi antara siswa dengan kecerdasan linguistik tinggi, sedang, atau rendah, (3) Apakah terdapat interaksi antara model pembelajaran Student Facilitator and Explaining (SFE) dan kecerdasan linguistik terhadap hasil belajar matematika siswa. Penelitian ini merupakan penelitian kausal komparatif dengan desain faktorial $3 \times 3$. Uji hipotesis menggunakan uji Anava dua jalan dengan sel tak sama. Kesimpulan penelitian ini adalah: (1) Tidak terdapat perbedaan hasil belajar matematika siswa antara model SFE dengan model konvensional (2) Tidak terdapat perbedaan hasil belajar matematika siswa ditinjau dari kecerdasan linguistik (3) Tidak ada interaksi antara model pembelajaran SFE dengan kecerdasan linguistik
\end{abstract} Kata Kunci: Hasil Belajar Matematika, SFE, Kecerdasan Linguistik

\section{PENDAHULUAN}

Berdasarkan dari hasil prasurvey yang dilakukan penelitian di SMA N 1 Seputih Surabaya diperoleh data tentang nilai ulangan tengah semester mata pelajaran matematika siswa kelas X semester genap tahun pelajaran 2015/2016, data sebagai berikut:

Tabel 1. Nilai Rata-rata Ulangan Tengah Semester Genap Siswa Kelas X SMA N

1 Seputih Surabaya Tahun Pelajaran 2015/2016

\begin{tabular}{ccccc} 
Mata Pelajaran & Matematika & PKn & Bahasa Indonesia & Bahasa Inggris \\
\hline Nilai Rata-rata Kelas & 65,63 & 75,79 & 80,03 & 70,94 \\
KKM & 70,00 & 73,00 & 72,00 & 71,00 \\
\hline
\end{tabular}

Sumber Data: Dokumentasi Buku Pendaftaran Siswa Kelas X SMA N 1 Seputih Surabaya Tahun pelajaran 2015/2016 pada tanggal 15 April 2016. 
Berdasarkan tabel data prasurvey menunjukkan bahwa nilai rata-rata matematika mencapai 65,63 dimana lebih kecil dari mata pelajaran PKn 75,79, Bahasa Indonesia 80,03 dan Bahasa Inggris 70,94 bahkan berada di bawah nilai kriteria ketuntasan minimal (KKM). Hal ini diasumsikan bahwa rendahnya hasil belajar karena matematika merupakan pelajaran yang cukup sulit bagi siswa, selain rendahnya sarana dan prasarana di sekolah sebagai penunjang pembelajaran, dan sifat karakteristik peserta didik, sebagian besar guru matematika masih menerapkan model pembelajaran mekanistik, dimana guru aktif memberikan informasi sedangkan peserta didik hanya menyimak, mencatat, dan mengerjakan latihan soal. Dalam pembelajaran mekanistik, peserta didik cenderung pasif dan hanya menerima penjelasan dari guru sehingga tujuan pembelajaran cenderung kurang tercapai secara optimal, supaya pembelajaran matematika dapat menghasilkan hasil yang optimal, hendaknya guru harus pandai memilih model pembelajaran yang mampu melibatkan peserta didik berperan aktif dalam proses pembelajaran (Primartadi, 2012). Kualitas pembelajaran yang baik tentunya akan menghasilkan hasil belajar yang baik pula, yaitu kemampuan yang diperoleh anak setelah melalui kegiatan belajar (Arifin Handoyo \& Arifin, 2016; Fitriana \& Ismah, 2016)

Model pembelajaran yang dipilih harus mampu membangkitkan motivasi atau gairah baik bagi peserta didik maupun bagi guru dalam proses pembelajaran sehingga dapat mencapai tujuan pembelajaran yang diinginkan dan memaksimalkan hasil belajar siswa. Terdapat banyak model pembelajaran yang dapat digunakan dalam pembelajaran matematika. Salah satunya yaitu model Student Facilitator and Explaining (SFE) dengan model konvensional. Model Student Facilitator and Explaining (SFE) disajikan materi ajar yang diawali dengan penjelasan secara terbuka, memberi kesempatan siswa untuk menjelaskan kembali kepada rekan-rekannya, dan diakhiri dengan penyampaian materi kepada siswa.(Muchyidin \& Kartika, 2014; Susanto, Suyitno, \& Arifudin, 2014)

Pembelajaran Student Facilitator and Explaining dapat memacu siswa untuk menggunakan kemampuan linguistik, diperlihatkan dalam bentuk kegiatan atau perilaku menggunakan bahasa dengan lancar, mampu mengekspresikan serta mengapresiasikan dan mengapersepsi kata-kata yang bermakna kompleks. Seseorang yang berkecerdasan linguistik mampu mengekspresikan semua idenya bisa melalui bentuk tulisan bahkan dalam berbicara. (Irvaniyah \& Oktaviana Akbar, 2014)

Penelitian terdahulu tentang penerapan model pembelajaran Student Facilitator and Explaining dilakukan untuk mengukur kemampuan pemahaman konsep, dan mengukur pemahaman matematika siswa. (Muchyidin \& Kartika, 2014; Susanto et al., 2014) Namun, belum ada penelitian sebelumnya yang menerapkan model pembelajaran Student Facilitator and Explaining terhadap hasil belajar dan ditinjau dari kecerdasan linguistik.

Berdasarkan penelitian yang telah dilakukan sebelumnya, keterbaruan dalam penelitian ini terletak pada penerapan model pembelajaran Student Facilitator and 
Explaining terhadap hasil belajar dan ditinjau dari kecerdasan linguistic siswa. Maka, tujuan dari penelitian ini adalah mengetahui pengaruh model pembelajaran Student Facilitator and Explaining terhadap hasil belajar dan ditinjau dari kecerdasan linguistik.

\section{METODE PENELITIAN}

Jenis penelitian ini adalah eksperimental semu (quasi eksperimental research) yang melibatkan dua kelompok, yaitu kelompok eksperimen dan kelompok kontrol, dengan analisis data menggunakan angka-angka atau penelitian kuantitatif. Adanya kesamaan ini ada yang karena diasumsikan, dikondisikan dan ada pula yang harus melalui pengujian dengan statistik uji, yaitu uji keseimbangan rata-rata yang digunakan untuk membuktikan bahwa kedua kelompok dalam keadaan seimbang sebelum perlakuan diberikan. Perlakuan yang diberikan kepada kelompok eksperimen adalah penerapan model pembelajaran Student Facititator and Explaining (SFE), sedangkan model konvensional diterapkan kepada kelompok kontrol.

Teknik pengumpulan data adalah metode dokumentasi, metode angket, dan metode tes. Instrumen penelitian terdiri atas tes penalaran matematis, angket motivasi belajar matematika dan tes prestasi belajar matematika pada materi bangun ruang sisi datar. Instrumen tes hasil belajar, mengacu pada kriteria yaitu validitas isi, daya pembeda $(D \geq 0,3)$ (Budiyono, 2011), tingkat kesukaran $(0,3 \leq P \leq 0,7)$, dan reliabilitas $\left(r_{11} \geq 0,7\right)$ (Budiyono, 2011: 17), dari 35 butir soal yang diujicobakan diperoleh 25 butir soal yang digunakan sebagai alat pengambil data prestasi belajar matematika siswa. Uji coba angket motivasi belajar matematika, mengacu pada kriteria yaitu validitas isi, konsistensi internal $(D \geq 0,3)$ dan reliabilitas $\left(r_{11} \geq 0,7\right)$, dari 40 butir pernyataan yang diujicobakan diperoleh 30 butir pertanyaan sebagai alat pengambil data motivasi belajar matematika.

Uji prasyarat analisis yaitu uji normalitas dengan Lilliefors dan uji homogenitas dengan uji Bartlett. Uji analisis data yang digunakan yaitu analisis variansi dua jalan dengan sel tak sama, dengan hipotesis:

Hipotesis pertama

$\mathrm{H}_{\mathrm{OA}}$ : Tidak terdapat perbedaan hasil belajar matematika siswa diajar menggunakan model pembelajaran SFE dengan model pembelajaran konvensional

$\mathrm{H}_{1 \mathrm{~A}}$ : Terdapat perbedaan hasil belajar matematika siswa diajar menggunakan model pembelajaran SFE dengan model pembelajaran konvensional

Hipotesis kedua

$\mathrm{H}_{\mathrm{OB}}$ : Tidak terdapat perbedaan hasil belajar matematika siswa ditinjau dari kecerdasan linguistik siswa.

$\mathrm{H}_{1 \mathrm{~B}}$ : Terdapat perbedaan hasil belajar matematika siswa ditinjau dari kecerdasan linguistik siswa. 
Hipotesis ketiga

$\mathrm{H}_{\mathrm{OAB}}$ : Tidak terdapat interaksi antara model pembelajaran dan tingkat kecerdasan linguistik terhadap hasil belajar matematika siswa

$\mathrm{H}_{1 \mathrm{AB}}$ : Terdapat interaksi antara model pembelajaran dan tingkat kecerdasan linguistik terhadap hasil belajar matematika siswa

\section{HASIL PENELITIAN DAN PEMBAHASAN}

Metode student facilitator and explaining merupakan pembelajaran dimana siswa atau peserta didik belajar mempresentasikan ide atau pendapat pada rekan, pembelajaran yang menjadikan siswa belajar sebagai fasilitator untuk mempresentasikan ide yang mereka buat dan diajak berpikir secara kreatif sehingga menghasilkan pertukaran informasi yang lebih mendalam dan menarik serta menimbulkan rasa percaya diri pada siswa untuk menghasilkan karya yang diperlihatkan kepada teman-temannya. Kelebihan metode pembelajaran ini diantaranya yaitu siswa dapat melatih keberaniannya untuk mempresentasikan materi yang akan dibahas. Siswa bisa lebih memahami materi sebelum pembelajaran karena sebelum pembelajaran berlangsung siswa dituntut memahami materi terlebih dahulu supaya dalam penyampaian materi tidak keluar dari indikator yang diharapkan. Namun kekurangannya karena dalam pembelajaran siswa yang lebih mendominasi terkadang siswa yang lain belum bisa menghargai temanya sendiri saat mempresentasikan materi. (Muchyidin \& Kartika, 2014)

Model Student Facilitator and Explaining (SFE) yang berisi langkah-langkah berupa informasi kompetensi, sajian materi, siswa mengembangkannya dan menjelaskan lagi ke siswa lainnya, kesimpulan dan evaluasi, serta refleksi. Penerapan metode SFE pada kelas eksperimen sebagai berikut:

1) Di awal guru menyampaikan kompetensi dan garis-garis besar materi pembelajaran.

2) Membagi kelompok-kelompok kecil yang terdiri dari 4-6 orang siswa.

3) Pada pembelajaran guru memberikan kesempatan kepada siswa untuk menjelaskan kepada siswa lainnya.

4) Dan di akhir guru memberikan apresiasi pada siswa yang menjadi Student Facilitator and Explaining.

Setelah siswa mengerti bagaimana menyelesaikan masalah pada aturan perkalian, permutasi dan kombinasi, kemungkinan kejadian dari berbagai situasi dan peluang kejadian melalui percobaan, guru memberikan tes kepada siswa berupa 30 soal pilihan ganda kecerdasan linguistik dan 6 soal uraian untuk melihat hasil belajar siswa. Soal tersebut sudah diuji tingkat validitas, reliabilitasnya, tingkat kesukaran dan daya beda, dan hasilnya semua soal layak untuk dijadikan alat ukur penelitian. 


\section{Hipotesis Pertama}

Hipotesis pertama adalah hasil belajar matematika siswa dengan model SFE sama dengan model konvensional. Berdasarkan hasil analisis variansi dua jalan sel tak sama untuk efek utama $\mathrm{A}$ (Model pembelajaran) diperoleh uji $\mathrm{F}_{\mathrm{a}}=1,40$ dan Ftab $=2,98$ sedangkan $\mathrm{DK}=$ $\left.\left\{\mathrm{F}|\mathrm{F}\rangle \mathrm{F}_{\alpha ; \mathrm{p}-1 ; \mathrm{N}-\mathrm{pq}}\right\}=\mathrm{F} 0,05 ; 1 ; 66=2,98\right\}$ sehingga $\mathrm{F}_{\mathrm{a}} \notin \mathrm{DK}$. Jadi $\mathrm{H}_{\mathrm{OA}}$ diterima, maka tidak terdapat perbedaan hasil belajar matematika siswa diajar menggunnakan model pembelajaran SFE dengan model pembelajaran konvensional. Tidak terpenuhinya hipotesis pertama kemungkinan disebabkan oleh beberapa faktor, diantaranya:

a) Siswa belum mampu menyesuaikan diri dengan adanya penerapan model pembelajaran Student Facilitator and Explaining (SFE) dalam pembelajaran karena terbiasa menggunakan model konvensional.

b) Kurangnya alokasi waktu untuk pembelajaran model pembelajaran Student Facilitator and Explaining (SFE) karena perlu mengkondisikan siswa ke dalam kelompok-kelompok dan membimbing siswa dalam berdiskusi kelompok.

c) Peneliti kurang mampu membimbing semua kelompok saat kegiatan diskusi berlangsung.

d) Siswa pemalu sering sekali sulit untuk mendemonstrasikan apa yang diperintahkan oleh guru.

e) Tidak semua siswa meiliki kesempatan yang sama untuk melakukannya (menjelaskan kepada teman-temannya karena keterbatasan waktu pembelajaran).

f) Siswa kurang bersungguh-sungguh dalam mengerjakan tugas-tugas yang diberikan guru.

2. Hipotesis Kedua

Hipotesis kedua pada penelitian ini adalah hasil belajar matematika siswa yang mempunyai kecerdasan linguistik siswa tinggi sama dengan siswa yang mempunyai kecerdasan linguistik sedang dan siswa yang mempunyai kecerdasan linguistik rendah,.

Dari hasil analisis variansi sel tak sama untuk efek B (Kecerdasan linguistik Siswa) diperoleh $F_{b}=2,81$ dan $F_{\text {tab }}=3,13$ sedangkan $\left.\left\{F|F\rangle F_{a ; q-1 ; N-p q}\right\}=F 0,05 ; 1 ; 52=2,98\right\}$ sehingga $F_{b} \in D K$. Jadi $\mathrm{H}_{\mathrm{OB}}$ diteima, maka tidak terdapat perbedaan hasil belajar matematika siswa ditinjau dari kecerdasan linguistik siswa.

3. Hipotesis Ketiga

Dari hasil analisis variansi dua jalan sel tak sama untuk efek $A B$ (Model pembelajaran dan Kecerdasan linguistik Siswa), diperoleh hasil uji $F_{t a b}=3,13$ sedangkan $D K=$ $\left.\left\{\mathrm{F}|\mathrm{F}\rangle \mathrm{F}_{\alpha ;(\mathrm{p}-1)(\mathrm{q}-1) ; \mathrm{N}-\mathrm{pq}}\right\}=\mathrm{F}_{0,05 ; 2 ; 52}=3,13\right\}$ sehingga $\mathrm{F}_{\mathrm{ab}} \in \mathrm{DK}$. Jadi $\mathrm{H}_{\mathrm{OAB}}$ diterima, maka tidak terdapat interaksi antara model pembelajaran dan tingkat kecerdasan linguistik terhadap hasil belajar matematika siswa. Ketidaksesuaian hasil penelitian dengan hipotesis ketiga ini mungkin disebabkan adanya siswa yang tidak jujur dalam mengisi soal dan dalam mengerjakan tes melakukan kerja sama dengan temannya. Akibatnya akan mempengaruhi 
logika teoritik yang seharusnya terdapat interaksi antara model pembelajaran dan tingkat kecerdasan linguistik siswa, tetapi kenyataan dari penelitian ini tidak terbukti.

Dalam penelitian ini banyak faktor yang tidak diperhitungkan dan ini merupakan keterbatasan dalam penelitian, sehingga jangan sampai terjadi persepsi yang salah pada penggunaan hasil penelitian. Faktor-faktor yang dimaksud seperti subyek penelitian, waktu pembelajaran, penyelenggara pemberi perlakuan dan evaluasi hasil belajar.

Subyek penelitian terbatas pada SMA N 1 Seputih Surabaya. Waktu pembelajaran terbatas pada kompetensi yang diajarkan yaitu peluang dan waktu pembelajaran juga tidak dapat dilaksanakan secara berturutan, hal ini dikarenakan penelitan ini dilaksanakan pada semester genap sehingga siswa kelas $X$ waktu pembelajarannya terganggu dengan kegiatan try out kelas XII untuk mempersiapkan Ujian Nasional. Dimana setiap kali pelaksanaan try out kelas XII, kelas X waktu pembelajarannya berkurang bahkan hilang karena diliburkan.

Dalam penyelenggaraan pembelajaran sepenuhnya diserahkan pada guru masingmasing sekolah sebagai tempat penelitian. Peran peneliti hanya sebatas pada pemberian arahan pada masing-masing guru untuk mentaati aturan yang sudah disepakati. Kesepakatan tersebut meliputi model pembelajaran yang digunakan, RPP yang sudah disiapkan, lembar kerja siswa, lembar tugas siswa dan alat evaluasi yang sudah dipersiapkan. Untuk menghindari bias dalam penelitian ini peran guru benar-benar dituntut selalu konsisten dan konsekwen dalam mentaati semua kesepakatan dalam melaksanakan penelitian.

Evaluasi hasil belajar terbatas pada tes tertulis yang berbentuk tes uraian sebagai akhir dari pembelajaran. Seharusnya evaluasi dilakukan sepanjang proses pembelajaran berlangsung. Untuk menjaga kesetaraan perlakuan pada dua kelompok yang berbeda sulit dilakukan, sehingga hasil penelitian ini harus diterima dengan hati-hati. Dalam mengerjakan soal tes kemungkinan masih ada siswa yang mengerjakannya tidak secara mandiri atau bekerja sama dengan siswa lainnya, sehingga data untuk hasil belajar matematika kurang murni. Demikian juga dalam mengisi soal kecerdasan linguistik siswa masih banyak siswa yang tidak jujur dalam mengisinya yang mengakibatkan kurang akurat dalam menentukan pembagian kelompok tinggi, sedang, dan rendah.

Bakat linguistik bersifat universal, dan perkembangannya pada anak-anak amat mengherankan, tidak berbeda pada budaya yang berbeda. Bahkan dalam populasi orang tuli dengan bahasa tanda manual tidak diajarkan secara nyata, anak-anak sering manemukan bahasa manual mereka sendiri dan menggunakannya secara sembunyi-sembunyi. Jadi, kecerdasan dapat beroperasi secara tidak tergantung pada input indera spesifik atau saluran output. Bahasa memiliki umur yang sama dengan umur bumi. Ketika kehidupan mulai muncul, seiring itu pula kehidupan bahasa mulai ada. Pada dasarnya, bahasa merupakan media seseorang untuk menyampaikan maksud dan keinginannya kepada lawan bicara, berupa bahasa tubuh atau hanya gerakan tangan. Bahasa yang merupakan kemampuan 
berkomunikasi dengan kata-kata adalah kemampuan istimewa pada manusia, yang kemungkinan berasal dari daerah tertentu yang spesifik pada korteks dibelahan otak sebelah kiri. Benturan keras pada kepala sebelah kiri dapat menyebabkan ketidakmampuan seseorang untuk mengerti atau menghasilkan kata-kata yang terucapkan, sedangkan benturan pada kepala sebelah kanan mungkin tidak. Kecerdasan bahasa berisi kemampuan untuk berfikir dan menggunakan bahasa dan kata-kata secara efektif, baik secara tertulis maupun lisan, dalam berbagai bentuk yang berbeda untuk mengekspresikan gagasangagasannya. Bahasa hanya rangkaian kata dan kata hanyalah rangkaian yang terdiri dari huruf sehingga bahasa hanyalah rangkaian huruf yang tersusun dengan makna dan maksud tertentu yang disebut kalimat. (Irvaniyah \& Oktaviana Akbar, 2014)

\section{SIMPULAN DAN SARAN}

Berdasarkan hasil analisis dan pembahasan terhadap uji hipotesis serta mengacu pada rumusan masalah, dapat disimpulkan bahwa tidak terdapat perbedaan hasil belajar matematika siswa antara model SFE dengan model konvensional, tidak terdapat perbedaan hasil belajar matematika siswa ditinjau dari kecerdasan linguistik dan tidak ada interaksi antara model pembelajaran SFE dengan kecerdasan linguistik.

Berdasarkan kesimpulan penelitian ini, dapat diajukan beberapa saran bagi peneliti selanjutnya, diharapkan dapat mengkaji masalah dengan jangkauan yang lebih luas demi perkembangan ilmu pengetahuan dalam dunia penelitian, yaitu hendaknya pada penelitian selanjutnya dapat mencoba menggunakan model-model pembelajaran lain untuk memaksimalkan hasil belajar, ataupun dapat menggunakan model SFE untuk mengukur kemampuan kemampuan yang ada dalam pembelajaran matematika, serta bukan hanya ditinjau dari kecerdasan linguistik namun dapat ditinjau dari segi yang lainnya.

\section{DAFTAR PUSTAKA}

Arifin Handoyo, N., \& Arifin, Z. (2016). Pengaruh Inquiry Learning Dan Problem Based Learning Terhadap Hasil Belajar PKKR Ditinjau dari Motivasi Belajar. Jurnal Pendidikan Vokasi, 6(1), 31-42.

Budiyono. (2011). Penilaian Hasil Belajar. Surakarta: UNS Press.

Fitriana, M., \& Ismah. (2016). Pengaruh Model Pembelajaran Auditory Intellectually Repetition Terhadap Hasil Belajar Matematika Siswa Ditinjau Dari Kedisiplinan Siswa. Jurnal Pendidikan Matematika Dan Matematika, 2(1), 59-68.

Irvaniyah, I., \& Oktaviana Akbar, R. (2014). Analisis Kecerdasan Logis Matematis dan Kecerdasan Linguistik Siswa Berdasarkan Jenis Kelamin. EduMa, 3(1), 138-159.

Muchyidin, A., \& Kartika, I. (2014). Perbandingan Pemahaman Matematika Siswa Antara Kelas yang Menggunakan Metode Student Facilitator And Explaining dengan Metode 
Peer Teaching Pokok Bahasan Bangun Ruang Sisi Datar. EduMa, 3(2), 76-94.

Primartadi, A. (2012). Pengaruh Metode Student Teams-Achievement Division (STAD) dan Problem Based Learning Terhadap Hasil Belajar Ditinjau Dari Potensi Akademik Siswa SMK Otomotif. Jurnal Pendidikan Vokasi, 2(2), 143-153.

Susanto, F., Suyitno, H., \& Arifudin, R. (2014). Komparasi Model Pembelajaran TPS dan SFE Terhadap Kemampuan Konsep. Unnes Journal of Mathematics Education, 3(1), 63-68. 